\title{
Assessment of the Sources of Pollution and of Surfaces Suitable for Bioretention Systems in Different Sites in Terms of Land Use
}

\author{
Păuniţa Iuliana BOANCA $\breve{1}^{\left.1^{*}\right)}$, Emil LUCA ${ }^{1)}$, Adelina DUMITRAȘ ${ }^{1)}$, Marcel DÎRJA ${ }^{1)}$, Laura LUCA ${ }^{2)}$, Răzvan \\ VASIU $^{1)}$, Georgeta BURDUHOS ${ }^{1)}$ \\ 1) University of Agricultural Science and Veterinary Medicine, Cluj-Napoca, 3-5, Manastur Street, \\ 400372, Romania \\ 2) Research Institute for Analytical Instrumentation, ICIA, 67, Donath Street, Romania \\ ${ }^{*}$ Corresponding author, e-mail: paunita_boanca@yahoo.com
}

Bulletin UASVM Horticulture 71(2) / 2014

Print ISSN 1843-5254, Electronic ISSN 1843-5394

DOI:10.15835/buasvmcn-hort:10279

\begin{abstract}
The knowledge of the rainwater runoff pollution sources and the flow pattern is essential in evaluation of storm water management options. The aim of the study was to identify the pollution sources, to establish the position of these sources and runoff pathways of the polluted rainwater; identify the areas where can be implemented the bioretention systems; the size analysis of the surfaces suitable for bioretention systems implementation based on location and land use. The study included four types of urban sites: commercial, industrial, low density residential and high density residential. The methodology of identification of diffuse pollution sources in the studied sites used field observation methods, imagery and GIS software. To properly identify the pattern of the stormwater runoff, field observations were made during the days with precipitation, between March 2012 and August 2014. For a clear results, were observed precipitations and runoff for each season separately, including snowfall (was followed water leakage pattern from melting snow). Precipitations with varying degrees of intensity were followed. The sources of diffuse pollution of stormwater runoff were determined on the basis of land use types. The results show that the diffuse sources of contamination of rainwater runoff are characteristic of the studied areas in close relationship with the land use type. The evaluation of suitable surfaces for bioretention implementation in ClujNapoca, by studying these four representative areas, shows that in all areas, regardless of the land use types, the surfaces are available for the implementation of these systems. The studied issue related to diffuse pollution sources and areas suitable for bioretention systems does not restrict and recommends their implementation.
\end{abstract}

Keywords: diffuse, pattern, pervious, pollution, runoff, urbanization

\section{INTRODUCTION}

The urbanization has an accentuated negative environmental impact through physical and chemical changes on the hydrologic system (Jacobson, 2011, Fletcher et al., 2013). Changing the land use affects both urban and periurban environment (Tavares et al., 2012). A large number of studies show increases of the impervious surfaces in relatively short periods of time (Gerard et al., 2010; Boancă-Pop et al., 2012; Zhou et al., 2012; Miller and Grebby, 2014). The urbanization affects the hydrological regime by increasing of the impervious surfaces (Braud et al., 2013). The existent studies indicate that the percent imperviousness of a catchment is an important and sensitive parameter in analysing the effects of urbanization of storm-water runoff (Kuichling, 1889; Arnold and Gibbons, 1996; Jacobson, 2011). Gallo et al. (2013) show that the effect of urban land cover on hydrologic responses was tightly coupled to the magnitude of rainfall and that runoff quality did not vary in response to impervious cover or land use (Gallo et al., 2013). The loss in pervious surfaces reduces the infiltration into soils, while the introduction of artificial drainage replaces natural pathways. Urban runoff is a major pollution 
source of the hydrographical networks (GromaireMertz, 1999; Fang Huang, 2010; Taebi and Droste, 2004). The management of urban stormwater through bioretention systems implementation is a sustainable solution (Scholz and Yazdi, 2009; Kazemi et al., 2009; Kazemi et al., 2011; Trowsdale and Simcock, 2011) but which depends on the type of existing surfaces (pervious and impervious) and of the pollution diffuse sources.

The knowledge of the diffuse pollution sources (D'Arcy et al., 2000) and rainwater runoff pattern is essential in assessing the stormwater management options. Although, in general, the literature provides comprehensive data related to the above issues, we believe that these aspects should be treated according to local conditions of a particular site. Implementation of the bioretention cells as sustainable solution for managing urban runoff depends on particular factors that must be treated fairly in terms of the given context: geographical coordinates, climate, localisation of the pollution sources, runoff patterns, degree of imperviousness and most importantly - areas available and suitable for the bioretention systems construction. The purpose of this paper is to determine if in Cluj-Napoca exist surfaces necessary for the implementation of the sustainable systems based on bioretention and if the land use affects the quality and quantity of these areas. In addition was aimed to identify diffuse pollution sources and to establish the runoff patterns in the studied areas. The coverage degree with impervious surfaces, the sources of diffuse pollution and runoff pattern varies both for the urban areas from Romania and the ones abroad. We consider that in order to obtain functional bioretention facilities, these elements should be considered and should be a preliminary basis in their implementation. The methods based on direct observation and GIS techniques, used in this study, can be applied successfully in order to obtain important data for modelling of the bioretention systems - regardless of the location of urban area.

\section{MATERIALS AND METHODS}

The assessment of studied sites followed wellestablished and significant steps in the research process of the bioretention cells implementation conditions: identification of the pollution sources and creating maps with these sources position and with the polluted rainwater pathways; identify the areas in which the bioretention systems can be implemented; size analysis of the areas suitable for the bioretention cells implementation, based on location and land use.

Identification of the diffuse pollution sources and runoff pattern. The methodology for the identification of diffuse pollution sources in the studied site - included: field observation methods, imagery and GIS software (Mitchell, 2005). For the correct identification of runoff pattern, field observations were made during days with precipitation, between March 2012 and August 2014. Photographs were made for each site, were noted flow directions and problematic zones in terms of pollution sources or rainwater stagnation. For clear results, field observations were made observing the precipitation and the runoff for each season separately, inclusive for snowfalls (was observed the pattern runoff of water from snow melt). Also, precipitations with different degrees of intensity were monitored. Pollution sources have been established on the basis of site characteristics (land use types). Maps that contain sources of pollution and stormwater runoff patterns from impervious surfaces were made based on satellite images, and photographs made during the field research. In the figure 1 are presented images taken during field observations.

Identification of the areas in which the bioretention cells can be implemented. The methodology used to identify this type of areas relied on classical methods (direct observation, photographs) and contemporary methods (satellite imagery, geographic information systems - GIS, and CAD software) (Berke et al., 2006; Malczewski, 2004; Miller and Grebby, 2014). Information extracted from the use of this methodology constituted a database used for specific analyses. Thus, using Google Earth Geographic Information System have been visualized sites components that on the field cannot be spotted easily. SketchUp software was used to import and scale the images taken from Google Earth and for making accurate maps of the areas in which the bioretention cells can be implemented. For identification of these areas were considered existing buildings, thoroughfares, existing green spaces and impervious areas that allow rehabilitation in terms of sustainable development. 

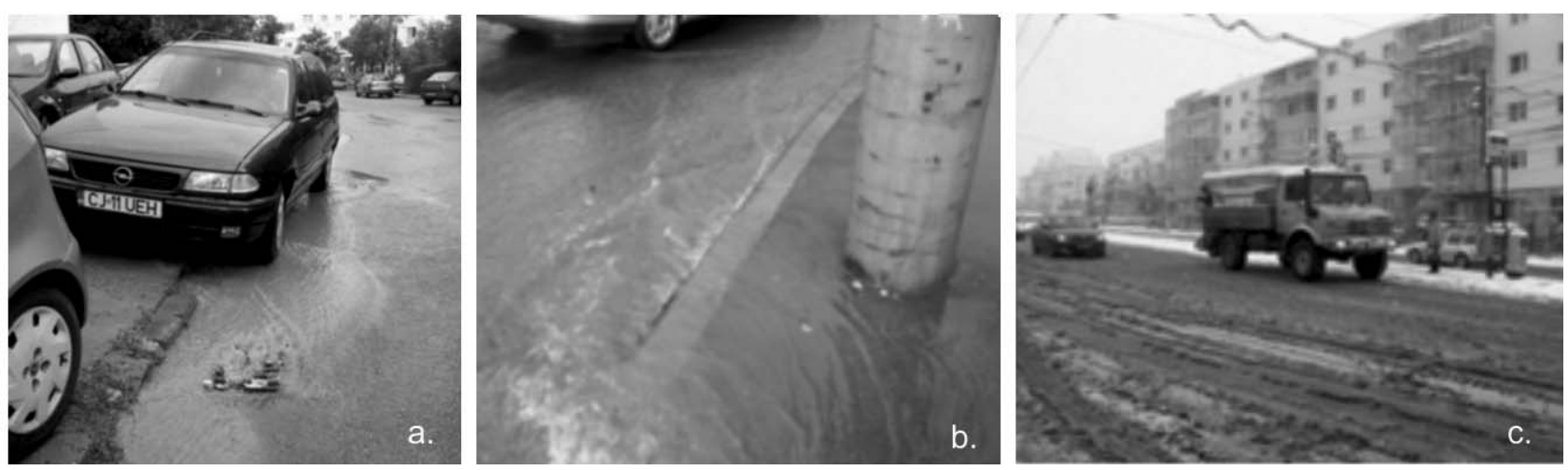

Fig. 1. Field observations during days with precipitation - Cluj-Napoca: a) Mehedinţi street, July 2013;

b)Primăverii street, May 2013; c) Primăverii street, February 2014
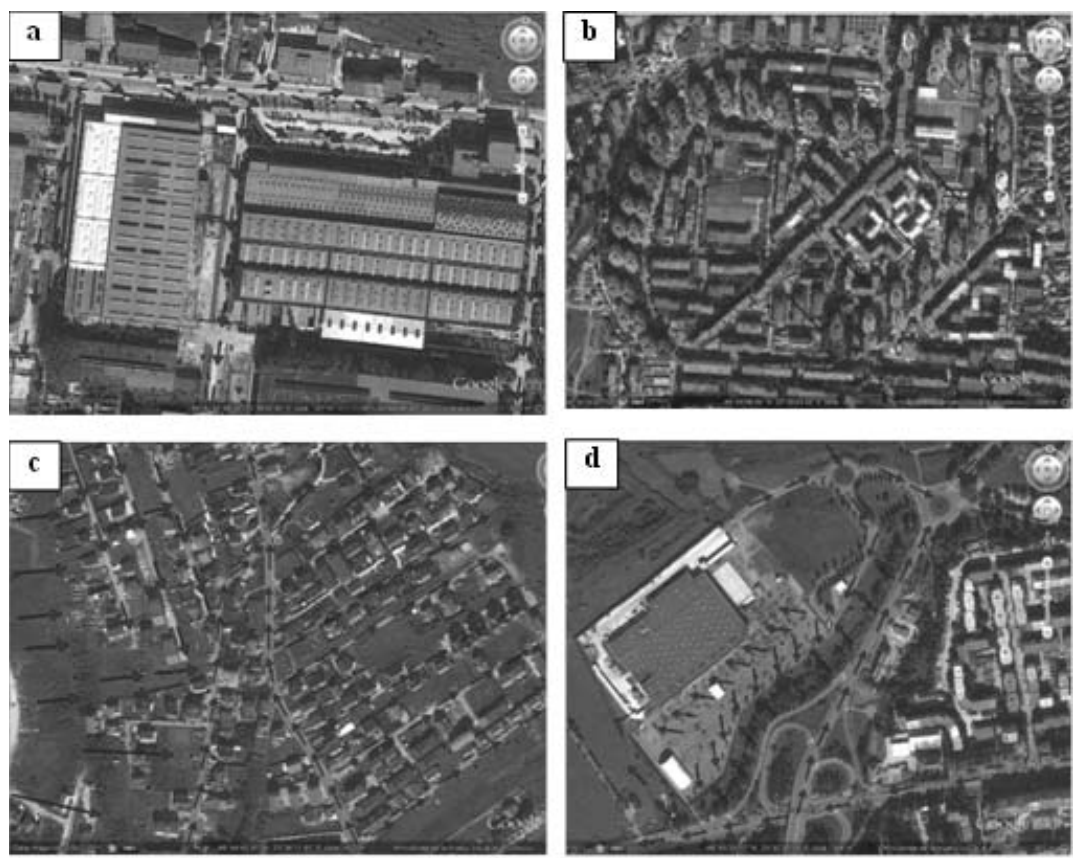

Fig. 2. Pluvial runoff pattern in studied sites: a) industrial area;

b) high density residential area; c) low density residential area; d) commercial area

Size analysis of areas suitable for the bioretention systems implementation based on location included the next steps: calculation of the areas available in each site; calculating the percentage of areas available from the total surface of each site individually; comparison of results (Christianson et al., 2004; Davis et al., 2009; Brown and Hunt III, 2011). Given that land availability may be limited depending on land use type, were calculated the impervious surfaces areas - existing green spaces in the studied areas. To be implemented, the bioretention cells require various surfaces, surfaces that under different conditions offered by the targeted sites restrict the implementation of these systems (Hitchcock et al., 2014).The aim was to obtain complete information for each site included in the research, being calculated for each site an equal area $(165,745.00$ $\mathrm{m}^{2}$ ). After the mapping and reconstruction of the components elements of the sites, were calculated areas occupied by roads, parking lots, buildings and green spaces/permeable surfaces.

\section{RESULTS AND DISCUSSIONS}

From the research process to identify the diffuse sources of rainwater runoff, the results 
show that they are characteristic to the studied areas and are in close relation to the land use type. The direct observation in field - during May 2012 and August 2013 - which included the observation of the activities in the four urban areas studied, showed that:

Inlow density residentialarea the identified the possible diffuse pollution sources are: automobile and activities of the residents: fertilizer, use of the herbicides, insecticides, fungicides, soil washing from the exposed areas in the private yards, detergents from car washing and other household activities, waste from pets, unmaintained septic systems, improper storage of paints, oils and other chemicals; small and medium coverage degree with impervious surfaces - represented by the roofs, walkways, streets, private parking; construction activities. In high density residential area the pollution sources identified are similar with those in low density residential area, with some differences: a high coverage degree of impervious surfaces and commercial activities. In the commercial area pollution sources identified are: parking and their related actions: washing of pavements, fuel and oil leaks etc.; car and pedestrian path; maintenance activities of green areas: fertilization, the use of fungicides, insecticides, herbicides. In the industrial area the pollution sources identified are: traffic, especially heavy car traffic; manoeuvring operation of contaminated water; various industrial activities; high coverage degree with impervious surfaces; improper storage, etc.

The research results on the runoff pattern are shown in Figure 2. The maps show that rainwater runoff follow the natural topography and the slope of built areas. Using the runoff pattern has been determined the locations for bioretention cell implementation. The results show that the stormwater runoff pattern follows the car and pedestrian traffic routes. Problematic points were identified during field observations. Problems are compounded by the large amounts of sediment from soil washing on steep slopes and transported to the sewage network. These problematic points are located at the intersections of secondary roads in slope with road.

In the figure 3 it can be observed the large amount of sediment transported by runoff from high and average intensity rainfall. The results of observations show that due to large impervious surfaces and water-related infrastructure, natural flow pattern is affected and changed.
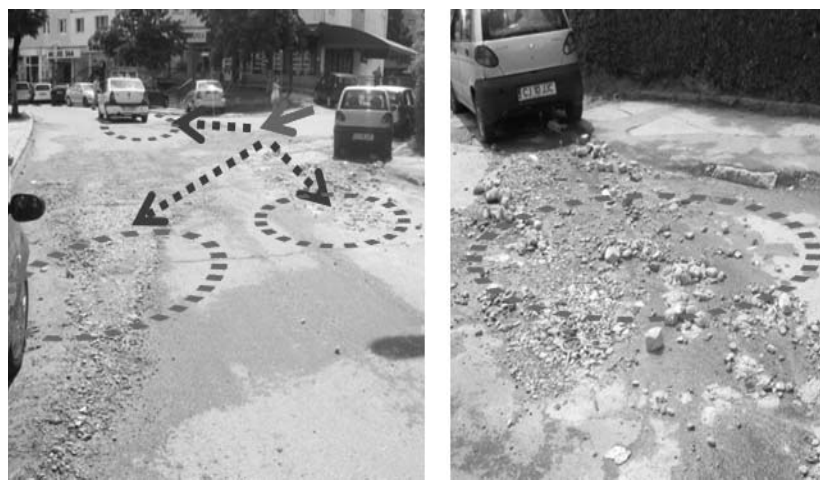

Fig. 3 Runoff pattern - sediment transported after soil washing

In low-density residential area results show that the bioretention cells can be implemented in areas with vegetation related to private property; in the green spaces adjacent to parking and streets; in areas with impervious surfaces (pedestrian path, parking, streets) where the dimensions allow restructuring through intercalation of preconstructed bioretention systems. In high density residential area the bioretention cells can be implemented, in general, in the green areas around of residential buildings, parking and streets (green spaces which delineates the pedestrian and cars circulation). In the industrial area, the results show that the areas available for bioretention cells are located near circulation routes, near industrial buildings, and in the area adjacent to the existing car parking. As a result of calculations made in order to analyse the size of areas suitable for the bioretention cells implementation based on location follows that:

In the low-density residential area: permeable surfaces/green spaces, where there is opportunity to be implemented the bioretention cells, occupy a percentage of $47 \%$; the buildings occupy $39 \%$, while the roads and parking lots occupy $14 \%$ of the studied area (Fig. 4).

In the high density residential area: has been identified an area suitable for bioretention cell implementation in a percentage of $44 \%$ of the total studied area; the rest of percentages are represented of $29 \%$ - roads and $27 \%$ - buildings (Fig. 5).

In the commercial area the resulted percentage is: $47 \%$ areas in which could be implemented 


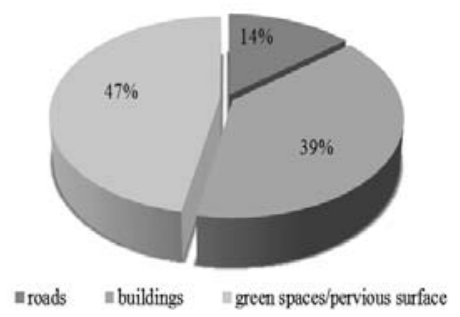

Fig. 4. Low density residential area

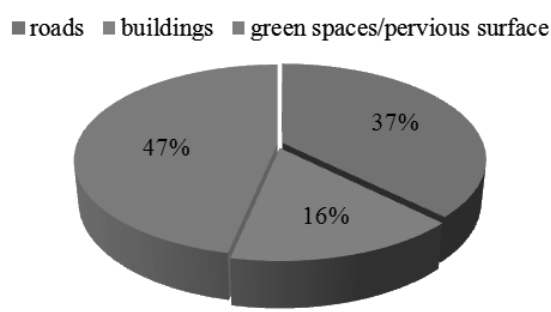

Fig. 6. Commercial area

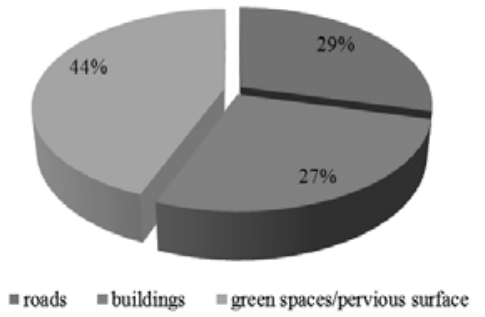

Fig. 5. High density residential area

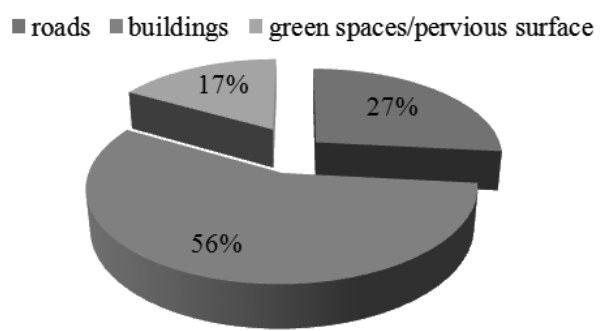

Fig. 7. Industrial area

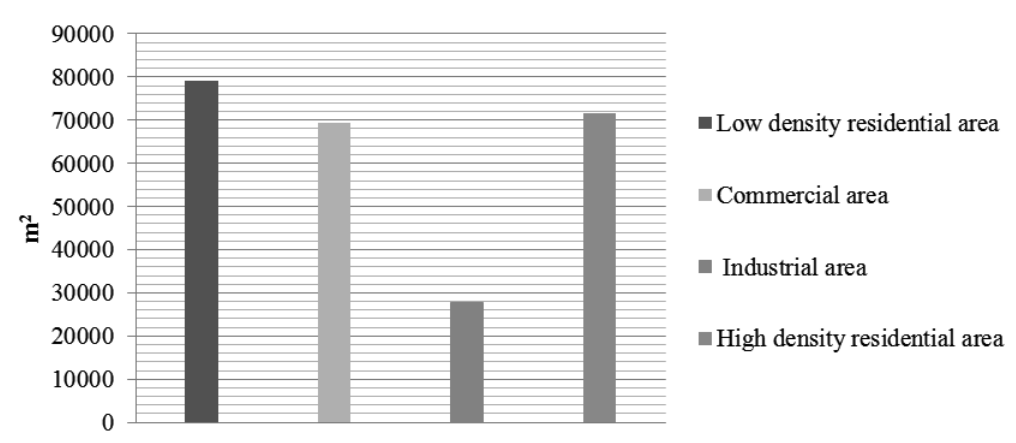

Fig. 8 Comparative analysis of suitable surfaces for bioretention cell implementation, identified in studied sites

bioretention systems; $37 \%$ surface occupied with roads and parking; $16 \%$ surface occupied with buildings (Fig. 6).

In the industrial area the results show that: the surfaces suitable for bioretention cells occupy only $17 \%$ from the total of the studied surface; the buildings occupy $56 \%$ from the total surface, and the roads and parking - 27\% (Fig. 7).

Discussions. The size of the bioretention cells is dictated by the size of the impervious surfaces in the targeted catchment area (Christianson et al., 2004; Davis et al., 2009; Brown and Hunt III, 2011). In order that bioretention facilities to capture the first $1.27 \mathrm{~cm}$ runoff from impervious surface, the area of bioretention cell must be 5\% from the impervious area (Hunt, 2003; UWExtension, 2003; MPCA, 2005; U.S. EPA, 2009) or, in the studied case, $202.522 \mathrm{~m}^{2}$ bioretention surface for $4046.9 \mathrm{~m}^{2}$ (0.406 ha) impervious surface. It is recommended that the minimum length and width of a bioretention cell to be $3 \mathrm{~m}$ and $4.5 \mathrm{~m}$. May be used smaller widths $-1.2 \mathrm{~m}$ - in the cases in which the stormwater runoff have a dispersed flow along the bioretention cells arranged in vegetable strips adjacent to car or pedestrian circulation routes. The results of the assessment of the surfaces suitable for bioretention cells implementation in Cluj-Napoca, through the study of four representative areas (commercial, industrial, low density residential, high density residential) show that in all areas, regardless of the land use type, are available implementation surface. The available surfaces, even if they are found in different proportions depending on the type of site (Fig. 8), 
meet the minimal condition of bioretention cells sizing - exposed above - conditions that ensure efficient operation and successful performance of these facilities functions.

The research presented in this paper started from the hypothesis that any pervious surface (in particular available green spaces) can be used for placement of bioretention cells -thus resulting larger areas of implementation, in a higher percentage than minimum standards. Given that there are certain types of areas undesirable for the bioretention cells construction, it was taken into account the exclusion from the suitable surfaces percentage, resulting from the assessment of sites in Cluj-Napoca. Even in the conditions of the exclusion of these surfaces, results a sufficient percentage of suitable area for bioretention systems. Undesirable areas to implement bioretention cells include: areas where mature trees were identified - to avoid the removal of this; areas where the existing slopes have an inclination degree of $20 \%$ or more, and area situated above or close to the unstable soil. It is recommended that in the residential area the bioretention cells to be combined with other stormwater runoff management practices. In the commercial area, the bioretention cells can be implemented successfully, the results showing that the suitable surfaces are adjacent to the parking lots, inside the parking lots and along the car and pedestrian circulation paths.

\section{CONCLUSION}

After this study we conclude that the methods used, even if it involves larger periods of time, are inexpensive and can be applied successfully in any urban area to obtain important data for correct implementation of the bioretention systems.

Regarding the sources of diffuse pollution after the investigations based on direct observation in the four urban areas studied in Cluj-Napoca - it resulted that they are influenced by the type of land use. To ensure extensive information we recommend further investigation on runoff pollutants loads in these areas.

Results on runoff pattern indicates that the natural topography has a great influence on them but that inclination of built areas should not be neglected - it has a rather large influence in urban area due to the high coverage degree with impervious surfaces.
The calculation for determining the surface available for the implementation of bioretention system show significant differences between the four areas studied. However the implementation of bioretention systems is not restricted in any of the studied areas by the available pervious surface.

We recommend performing these types of studies - regardless of the location of urban areas in Romania or abroad - when planning the implementation of the facilities based on bioretention. Thus will be avoided initial errors that could lead to bioretention systems with compromised function.

Acknowledgments. This paper was published under the frame of European Social Fund, Human Resources Development Operational Programme 20072013, project no. POSDRU/159/1.5/S/132765.

\section{REFERENCES}

1. Arnold CL, Gibbons CJ (1996). Impervious surface coverage: The emergence of a key environmental indicator. J. Am. Plan. Assn. 62(2):243-250.

2. Berke P, Godschalk, DR, Kaiser, EJ (2006). Urban land use planning. University Of Illinois Press.

3. Braud I, Breil P, Thollet F, Lagouy M, Branger F, Jacqueminet C, Kermadi S, Michel K (2013). Evidence of the impact of urbanization on the hydrological regime of a mediumsized periurban catchment in France. J. Hydrol. 485:5-23.

4. Brown RA,William F Hunt III (2011). Impacts of Media Depth on Effluent Water Quality and Hydrologic Performance of Undersized Bioretention Cells. J. Irrig. Drain Eng. 137, Special issue: Urban Storm-Water Management in the 21st Century, 132-143.

5. Christianson RD, Barfield BJ, Hayes JC, Gasem K, Brown GO (2004). Modeling Effectiveness of Bioretention Cells for Control of Stormwater Quantity and Quality. Critical Transitions in Water and Environmental Resources Management, 1-7.

6. D’Arcy BJ, Ellis JB, Ferrier RC, Jenkins A, Dils R (2000). Diffuse pollution impacts: The environmental and economics impacts of diffuse pollution in the UK. Chartered institute of water and environmental management (CIWEM), Terence Dalton Publishers, Lavenham.

7. Davis AP, William F Hunt, Traver RG, Clar M (2009). Bioretention Technology: Overview of Current Practice and Future Needs. J. Environ. Eng., 135(3):109-117.

8. Fang H, Wang X, Liping L, Zhiqing Z, Jiaping W (2010). Spatial variation and source apportionment of water pollution in Qiantang River (China) using statistical techniques. Water Research, 44(5):1562-1572.

9. Fletcher TD, H. Andrieu PH (2013). Understanding, management and modelling of urban hydrology and its consequences for receiving waters; a state of the art review. Adv. Water Resour. 51:261-279. 
10. Gallo EL, Brooks PD, Lohse KA, JET McLain (2013). Land cover controls on summer discharge and runoff solution chemistry of semi-arid urban catchments. Journal of Hydrology, 485:37-53.

11. Gerard F, PetitS, Smith G, Thomson A, Brown N, Manchester S, Wadsworth R, Bugár G, Halada, L., Bezak, P., Boltiziar, M., De badts, E., Halabuk, A., Mojses, M., Petrovic, F., Gregor M, Hazeu G, Mucher C, Wachowicz, Huitu M, Tuominen, H, Kohler S, Olschofsky R, Ziese K, Kolar H, Sustera J, Luque J, Pino S, Pons J, Roda X, Roscher F, Feranec MJ (2010). Land cover change in Europe between 1950 and 2000 determined employing aerial photography. Prog. Phys. Geogr. 34 (2):183-205.

12. Gromaire-Mertz MC, Garnaud S, Gonzalez A, Chebbo G (1999).Characterisation of urban runoff pollution in Paris. Water Science and Technology, 39(2):1-8.

13. Hitchcock DR, Jayakaran AD, White DL (2014). Green Infrastructure in Coastal Landscapes: Hydrological Function, Ecological Design and Sustainable Land Use Guidance. Journal of South Carolina Water Resources, 1(1), 32-38.

14. Hunt WF (2003). Bioretention use and research in North Carolina and other Mid-Atlantic states. NWQEP Notes. 109:1-10.

15. Jacobson CR (2011). Identification and quantification of the hydrological impacts of imperviousness in urban catchments: a review. J. Environ. Manage. 92:1438-1448.

16. Kazemi F, Beecham S, Gibbs J (2009). Streetscale bioretention basins in Melbourne and their effect on local biodiversity. Ecological Engineering, 35(10):1454-1465.

17. Kazemi F, Beecham S, Gibbs J (2011). Streetscape biodiversity and the role of bioretention swales in an Australian urban environment. Landscape and Urban Planning. 101(2):139-148.

18. Kuichling E (1889). The relation between rainfall and the discharge of sewers in populous districts. Trans. ASCE, 20:1-56.

19. Malczewski J (2004). GIS-based land-use suitability analysis: a critical overview. Progress in Planning, 62(1), 3-65.
20. Miller JD, S Grebby (2014). Utilizing aerial photography with topographical maps for long-term temporal mapping of imperviousness. Int. J. Appl. Earth Obs.Geoinform. 30, 9-20.

21. Mitchell G (2005). Mapping hazard from urban non-point pollution: A screening model to support sustainable urban drainage planning. J. Environ. Manage. 74(1), 1-9.

22. MPCA (2005). Bioretention. 2005 Minnesota Stormwater Manual, Version 1.0, Chp 12-BIO, 2.

23. Pop (Boancă) PI, M Dîrja, A Dumitraş (2012). Researches regarding the evolution of impervious surfaces in different sites in terms of land use in Cluj-Napoca for bioretention cells implementation. Bulletin UASVM Horticulture, 69(2):489-498.

24. Scholz M, Yazdi SK (2009). Treatment of road runoff by a combined storm water treatment, detention and infiltration system. Water Air Soil Pollut. 198 (1-4):55-64.

25. Taebi A, R L Droste (2004). Pollution loads in urban runoff and sanitary wastewater. Science of the Total Environment, 327(1-3):175-184.

26. Tavares AO, RL Pato, MC Magalhães. (2012). Spatial and temporal land use change and occupation over the last half century in a peri-urban area. Appl. Geogr. 34:432444.

27. Trowsdale SA, R Simcock (2011).Urban stormwater treatment using bioretention. Journal of Hydrology, 397 (3-4), 3:167-174.

28. U.S. EPA (2009). http://www.epa.gov/nps/toolbox/ other/cwc_raingardenbrochure.pdf.

29. University of Wisconsin-Extension (2003). Rain Gardens: A How-To Manual for Homeowners, UWEX Publication GWQ037.

30. Zhou B, Hong SH, Nigh TA, Schulz JH (2012). Mapping and analysing change of impervious surface for two decades using multi-temporal Landsat imagery in Missouri. International Journal of Applied Earth Observation and Geoinformation, 18:195-206. 